International Journal of Linguistics, Literature and Culture
Available online at https://sloap.org/journals/index.php/ijllc/
Vol. 7, No. 4, July 2021, pages: 263-273
ISSN: 2455-8028
https://doi.org/10.21744/ijllc.v7n4.1795

\title{
Pragmatic Approach to Indonesian Speaking Skills for Student Vocational High Schools
}

Veronika Unun Pratiwi a Muhammad Rohmadi ${ }^{b}$

Article history:

Submitted: 9 March 2021

Revised: 18 April 2021

Accepted: 24 May 2021

\section{Keywords:}

appropriate language;

Indonesian speaking;

interpreting data;

language learning;

pragmatic approach;

speaking skills;

\begin{abstract}
The Indonesian language serves as a bridge between the various languages, customs, ethnicities and cultures in the country. The problem that occurs in class is that students are less able to speak Indonesian well and are not in accordance with the situation and context, so there is a need for learning innovation. Purpose (1). Students are able to communicate well (2). Practicing oral expressions between teachers and students (3). The learning process of speaking Indonesian subjects. The research method used a descriptive qualitative approach. Supporting instruments in this study by observing, processing and interpreting data in accordance with the objectives. Data collection techniques through (a). Interview (b). Observation (c). Take notes. The analysis process is in accordance with the following stages: (1) data collection; (2) data reduction; (3) presentation of data (4) draw conclusions. Conclusion: Appropriate language competence in language learning is supported through structural language learning. Through learning about external aspects that often affect the communication process. Learning speaking skills through a pragmatic approach is effective in enhancing active learning, and improving students' speaking skills inside and outside the classroom.
\end{abstract}

International journal of linguistics, literature and culture (O) 2021. This is an open access article under the CC BY-NC-ND license (https://creativecommons.org/licenses/by-nc-nd/4.0/).

\section{Corresponding author:}

Pratiwi, P.U.

Doctorate Program in Indonesian Language Education, Sebelas Maret University and Veteran Bangun Nusantara University, Sukoharjo, Indonesia

Email address: pratiwiunun@yahoo.co.id

\footnotetext{
a Doctorate Program in Indonesian Language Education, Sebelas Maret University and Veteran Bangun Nusantara University, Sukoharjo, Indonesia

b Postgraduate Program, Sebelas Maret University, Surakarta, Indonesia
} 


\section{Introduction}

Language learning is, at its core, communication learning. Indonesian language learning in schools aims to improve students' verbal communication skills (Kusmiarti, 2020). Language is used for a variety of purposes and is presented in meaningful contexts rather than loose phrases. As a result, an approach in education, particularly in learning, that combines these conditions or objectives must be extensively studied (Davies, 2007). In the 2013 Curriculum as currently still applied in Indonesian curriculum, Indonesian language teaching was aimed at encouraging the use of Indonesian language for communication as well as fostering a positive attitude toward Indonesian language, rather than simply acquiring knowledge of the language itself. However, what happens in the field does not correspond to what has been hinted at. As a result, the 2013 curriculum is expected to bring a fresh perspective to Indonesian teaching. Teachers should focus on teaching Indonesian language skills such as listening, reading, speaking, and writing instead of linguistic knowledge (Mulyani, 2015).

Language teaching and learning orientation based on communication tasks and functions is called a communicative approach (Nababan, 1987). In the world of language teaching, the pragmatic term which is identical and is used interchangeably with the communicative term is used to refer to the competencies that are the objectives of teaching, the functions that are the teaching material, and factors that limit the competencies and functions taught (Yohanes, 2006; Tarvin, 2014). The communicative approach, according to this perspective, is an alternative to coping with these needs or demands. The communicative approach emphasizes the role of language in communication. This is what happens when language learning is conducted in a communicative manner.

Language learning, which is aimed at improving communication skills, can also be approached through one of the fields of language studies, namely pragmatics. Teaching language with a pragmatic approach is commonly referred to as a communicative function with multiple functions (Deda, 2013; EL Fattah Torky, 2006). Pragmatics is a branch of the study of language signs that deals with the selection of language forms and their meaning in relation to the speaker's intent in accordance with the context and state of the utterances produced by a speaker. Pragmatics, according to Leech (1983), is a language study that seeks to find situationally appropriate speech meanings. Meanwhile, pragmatics, as defined by the International Pragmatics Association (IPRA), is the study of language that is concerned with the intricacies of language use and its functions.

In Indonesian-speaking societies, Indonesian, like the role of language in general, is a medium for communication in the sense that it is used for formally and informally communication between individuals. As a result, it is hoped that speakers of this language will be able to understand and use Indonesian language according to the individuals involved in the conversation, the situation and conditions of the conversation, the applicable Indonesian language rules, and so forth. Despite what has been stated above, the teaching of Indonesian, particularly in schools, remains a source of concern. This is based on observations and research findings, which provide an overview, among others; teaching Indonesian language emphasizes theory more than practice; teaching too much about language lacks mastery of the language itself; teaching mostly discusses language elements, such as phonology, morphology, and syntax, with little training in using these elements; teaching mostly discusses the structure of the language; teaching mostly discusses the structure of the language itself; teaching mostly discusses the structure of the language itself (Kusmiarti, 2020) teaching mostly discusses the structure of the language itself; Teaching does not emphasize the ability to use language appropriately in different situations (pragmatics); the curriculum is designed in such a way that it allows for misinterpretation; and teachers frequently see only the subjects and their discussions, regardless of the teaching objectives that have been outlined (Angelina, 2019). The assessment system is in the form of a final exam, and UAN and the like tend to emphasize cognitive aspects while placing less emphasis on language skills.

The above-mentioned condition of teaching Indonesian language is what encourages the Pragmatic element to be included in the current curriculum, particularly at the vocational school levels. This is to emphasize the types of Indonesian language skills that are explicitly stated in the 2013 Curriculum. With the addition of Pragmatics as a separate subject to the Indonesian language teaching model, students are expected to be able to use Indonesian language communicatively and understand individuals' utterances in a given situation.

The ability to study things other than the language will undoubtedly help students apply their language skills practically in real-life situations. It is hoped that by using a pragmatic approach to language learning, students will be able to apply their language skills in everyday situations in society. Aside from the previously mentioned topics, this article is a theoretical investigation into the use of the pragmatic approach in high schools. This will be a critical examination of a number of theories in order to reach effective conclusions. 


\section{Materials and Methods}

This study was designed with a qualitative descriptive method. The object study covers conversational utterances of teachers and tenth-grade students at the Vocational High School (SMK) 1 of Sukoharjo. Data were collected in January to February 2021 with techniques or samples aimed at aligning with the problem. Data collection used the observation and note-taking technique. Data analysis was undertaken using the flow technique of Miles \& Huberman (2002) and Sutopo (1996). The data analysis process was carried out in stages: (1) data collection; (2) data reduction; (3) presentation of data; and (4) drawing conclusions. Thus, the data analysis process and conclusions were carried out from beginning to end.

\section{Results and Discussions}

\section{Pragmatics in language teaching}

A learning model with a pragmatic approach incorporates pragmatic elements into pedagogical interventions. Pragmatics is the study of a speaker's intent, contextual meaning, expressions with a relative distance, the relationship between signs and their translations, and the barriers to using language in social interactions (Crystal, 1985; Levinson, 1997; Yule, 2000). Pragmatic elements include pragmalinguistic understanding and sociopragmatic knowledge. Pragmalinguistics explores the linguistic aspects of utterances, whereas sociopragmatics examines these utterances concerning their social context (Leech, 1983).

The approached learning model developed includes and conditions all aspects of learning with these two pragmatic elements (pragmalinguistic and sociopragmatic), such as teaching materials, learning procedures (lesson plan), and syllabus. This learning model was validated by several experts before it was declared valid for use. Pragmatic teaching explicitly is learning English with pragmatic coverage which is done directly (Jorda, 2004). When transferring teaching materials, pragmatic coverage is introduced directly and without implication. When teaching English, the lecturer introduces "refusal and request" semantic formulas. According to Ortega (2011), learning English with an explicitly pragmatic approach can be accomplished by providing tasks or activities that can increase students' pragmatic awareness and other activities that can provide students with opportunities to practice communication or activities that provide communication practice (Ortega, 2011).

In practice, students are encouraged to observe pragmatic aspects of the target language in spoken and written discourse, as well as to participate in group interactions in which they participate in oral role plays and simulations. This is done so that students can increase their awareness of pragmatic aspects, as pragmatic learning is thought to have an effect on students' level of pragmatic competence (Kasper, 1999). Eslami-Rasekh et al. (2004) propose another applicable method of pragmatic learning, namely conducting teacher-guided discussions, cooperative groups, role plays, and other pragmatic-oriented activities. It was concluded that by implementing such techniques, students' understanding of speech acts was significantly improved (Rohmadi, 2014).

Language assessment in pragmatics is based on how language is used rather than just its structure. Contexts surrounding a language will be given special consideration about the meaning derived from language usage. In pragmatic assessments, the practical conditions of communication acts take precedence. Thus, in this case, the discourses related to the communication process is the primary concern of pragmatic studies (Rohmadi, 2014). The Pragmatics reading language evaluation delves further into the abilities to communicate effectively in all contexts that underpin linguistic relations between humans as members of society. This perspective describes pragmatic orientation in practical communication, in which different factors appear outside of language that lead to meaning in the communication process at the practical level (Arsyad, 1997). According to Nababan (1987), there are a variety of deciding factors in communication, among others are, who speaks; with whom; for what purpose, under what circumstances, (place and time); in what context (other participants, culture and atmosphere); by what route (oral or written); what media (face to face, telephone, letter, etc.); in what event (conversations, lectures, ceremonies, reports, etc.). According to this perspective, several factors that are likely to influence the act of communication are actors, objectives, situations, context, channels, media, and events. It is consistent with Nababan (1987), who proposes three basic concepts in language use (pragmatic studies), namely communication acts, communication events, and communication situations.

Pratiwi, V. U., \& Rohmadi, M. (2021). Pragmatic approach to Indonesian speaking skills for student vocational high schools. International Journal of Linguistics, Literature and Culture, 7(4), 263-273. https://doi.org/10.21744/ijllc.v7n4.1795 
Based on the aforementioned, it is clear that pragmatics is extremely beneficial in language teaching, particularly in schools. Language teaching that is oriented toward language studies in a "structural" manner will undoubtedly create many obstacles when it is unrelated to the practical use of language in the field. A person's pragmatic quality is required in language activities. It is expected that students will be able to use the target language in accordance with the context that underpins real-world activities through pragmatics (Nurhadi, 1995). As a result, the communication that takes place is geared toward achieving pragmatic quality, so that students can use language appropriately for the situation.

Language learning should be able to meet the language needs practice in real-world situations. The language learning process received by students will automatically refer to a practical condition of communication action with a pattern based on pragmatic studies. Such a learning orientation will necessitate changes to various aspects of learning, from the curriculum to the practical level of learning. According to Arsyad (1997), three important aspects of this viewpoint are learning programs, different languages, and training based on the situation and context. These three factors are critical when language learning is geared toward the practical application of language. When the ultimate goal of language learning is "students can communicate effectively and efficiently following applicable ethics, both orally and in writing," it is clear that creating an appropriate situation and context is unavoidable (BSNP, 2006).

There are other viewpoints that contribute to other aspects other than language: because ideas about problems related to science, technology, and/or the culture being studied are expressed in this lesson, teaching Indonesian should be based on a cultural dimension (Widiasri et al., 2019). Teaching is centered on developing proficiency in using correct, clear, effective, and functional language as a means of communication. This tries to incorporate a cultural dimension because it is related to other aspects of life. Indeed, when humans express their ideas, they use a language, which eventually clashes with other aspects. As a result, if language learning had to be based on real-world situations, it would be very acceptable. Based on the various explanations given above, it is possible to conclude that language learning aimed at the practical level of communication actions will be necessary for students. In this case, the communicative approach (specifical pragmatics) is extremely helpful in directing the language learning process, especially in formal or school education.

\section{Curriculum studies concerning the pragmatic approach}

Students must genuinely master communication skills (real language functions). This ensures that students are able to interact in a number of situations. The communication partner, the message communicated, the communication method, as well as the time and location of communication are all part of the situation's context. As a result, the interactions that occur take into account not only the accuracy of communication, but also the language conduct (communication) that represents the Indonesian nation's values. Since interacting entails not only comprehending, but also appreciating and developing personality. One of the concerns of the Indonesian government, expressed through its minister of education, is to enhance the standard, effectiveness, performance, and relevance of education in light of cultural influences and times by imposing a new curriculum, known as the 2013 Curriculum. The primary aim of studying Indonesian in schools is for students to be able to communicate in the language. Language learning has been aimed at the ability to interact practically from basic education to high levels of education.

It is not possible to achieve a "good" ability to communicate solely by studying language structurally. This is due to the fact that many factors other than language influence the communication process. In this case, the pragmatic approach to language learning, which is oriented toward practical communication acts, is quite beneficial. The formation of directions in this most recent curriculum has also included a lot of pragmatic studies in it. The various competency demands presented are also based on communication actions (pragmatics). Competency standards and basic competencies as learning references have been designed to meet the demands of "students are able to communicate effectively and efficiently in accordance with applicable ethics, both orally and in writing." It is based on communication needs when it comes to listening, reading, speaking, and writing. In learning these four aspects, it will always be directed to the ability to capture discourse that lies outside the structural aspects of language. With a good understanding of things outside of language, students are expected to be able to interpret a language better, and furthermore students are expected to be able to communicate better as well.

All aspects of education must unambiguously support such planning. When a concept is good, but it is not carried out according to the directions at the practical level, the results will be suboptimal. With this most recent curriculum, it is clear that the teacher, as one of the most important elements, has the flexibility to design a learning process that is tailored to the needs of the students (EL Fattah Torky, 2006; Evans \& Green, 2007). Each region will experience 
unique phenomena, particularly when it comes to language use. What teachers must remember is that there are competency standards and fundamental competencies that must be met. The rest becomes educational policy in order to accommodate communication needs.

\section{Speaking subject}

Speaking is a means of communicating ideas that are structured and developed to meet the demands of the listeners. Learning to speak is inextricably linked to learning the Indonesian language because, according to its position and function, the goal of learning the Indonesian language is to enable students to use the language properly and correctly in various communication events, both orally and in writing. Learning to speak must be accomplished by establishing learning situations that allow students to practice speaking as much as possible. Teaching and learning activities must always provide opportunities for students to practice speaking because speaking skills can only be mastered properly if the speaker is given as much practice as possible.

Providing as many speaking opportunities as possible is one of the principles used in learning to speak. This requires practical exercises that are performed on a regular and directed basis. As a result, students not only understand the theory of speaking, but they also practice applying the theory in the most natural settings possible. Then, speaking practice is incorporated into the daily learning program. Because coordination is needed between Indonesian language teachers and teachers of other subjects in terms of providing opportunities for students to practice speaking so that students actively practice speaking in a proper communication. This can foster self-esteem. A lack of self-confidence is one of the challenges that a student faces. Regular speaking exercises are extremely beneficial to students' self-confidence. Attempts to boost self-confidence when speaking, for example, by first attempting to master what to say to the listeners; then organizing the problems to be conveyed systematically so that they become appealing to the interlocutor; and ensuring that what is being conveyed is the right thing and is important and beneficial to the listeners. This belief will make the speaker more courageous to appear in front of the listener, resulting in increased self-confidence. Think openly and casually, and imagine the listener as someone who has no idea what to say. Instead, listeners should be informed about what they will be discussing (Depdiknas, 2004) The teacher should consider the points raised above when selecting and determining speaking learning material. This belief will make the speaker more courageous to appear in front of the listener, resulting in increased self-confidence.

\section{Speaking as a communication skill}

This belief will make the speaker more courageous to appear in front of the listener, resulting in increased selfconfidence. Think openly and casually, and imagine the listener as someone who has no idea what to say. Instead, listeners should be informed about what they will be discussing (Depdiknas, 2004) The teacher should consider the points raised above when selecting and determining speaking learning material. This belief will make the speaker more courageous to appear in front of the listener, resulting in increased self-confidence.

According to the 2013 curriculum, Indonesian language learning focuses on the realization of students who master four language skills, namely listening, speaking, reading, and writing. These four skills are inextricably linked. Nonetheless, each skill has its own territory and independence. This can be seen in the brain's movements at work. It turns out that the part of the brain that works differs depending on whether the test involves reading, listening, talking, or considering the meaning of a word (Cavendish, 1995; Van Wynsberghe \& Robbins, 2014). Speaking is a type of oral communication activity. Effective communication involves not only what a person says, but also how he says it. This relates to both linguistic and non-linguistic concerns. There are at least two types of factors that contribute to the effectiveness of speaking: linguistic factors and non-linguistic factors. Linguistic factors include: accuracy of speech; appropriate pressure, tone, and duration; word choice; and accuracy of target conversation. Meanwhile, non-linguistic factors include: a reasonable, calm, and not rigid attitude; a look at the interlocutor; a willingness to respect the opinions of others; precise gestures and expressions; loudness of voice; smoothness; reasoning; and topic mastery (Paul, 2008; Taguchi, 2018).

The act of speaking is not an inherited skill passed down from parents. Speaking is a skill that must be learned, and it is used for a variety of purposes depending on what the speaker wishes to convey, such as: stating factual information (identify, report, ask, correct), expressing intellectual attitudes (agree or disagree, arguing, and so on), expressing moral attitudes (apologizing, expressing regret, appreciation, and so on), and expressing orders (inviting, inviting, warning, and so on). Speaking, as Tarigan points out, is more than just pronouncing sounds or words. Speaking is a tool for communicating ideas that have been structured and developed to meet the needs of the listener

Pratiwi, V. U., \& Rohmadi, M. (2021). Pragmatic approach to Indonesian speaking skills for student vocational high schools. International Journal of Linguistics, Literature and Culture, 7(4), 263-273. https://doi.org/10.21744/ijllc.v7n4.1795 
or listeners (Tarigan, 2008; del Saz Rubio, 2011; Holland, 1991). Speaking, according to this definition, is the ability to pronounce articulated sounds or words in order to express, express, and convey thoughts, ideas, and feelings to others. A series of pitches, stresses, and pauses are used to convey information to the listener. When communicating face-to-face, the speaker's expression and pantomimic gestures can help the speaking process.

\section{Non-linguistic aspects}

In a formal conversation, mastery of the non-linguistic aspect facilitates the application of the linguistic aspect. Nonlinguistic aspects include, for example, a reasonable attitude that is calm and not stiff; eyes that are directed at the interlocutor. The ultimate goal of language learning is to develop communicative abilities, specifically the ability of a person to not only use language rules to compose sentences grammatically but also to use those sentences to communicate contextually. There are five components that make up communicative abilities: a. grammatical mastery, which includes mastery of language rules that allow a person to distinguish between correct and incorrect sentences. b. Sociolinguistic ability, or the ability to use language appropriately in relation to its context. c. Psycholinguistic ability, or the ability to use language in a psychologically sound manner. d. Discourse ability, or the ability to use language in a specific context or discourse. e. Strategic ability, i.e. the ability of a person to make communication run smoothly or to stutter communication. The table below describes various guidelines for assessing speaking activities based on supporting factors.

Table 1

Guidelines for assessing students' speaking activities

\begin{tabular}{ll}
\hline Linguistic factors & Non- Linguistic factors \\
\hline vowels expression & courage and passion \\
consonants expression & smoothness \\
pressure fixing & voice loudness \\
joint placement & eyes sight \\
the use of a rhythmic tone & gestures and expressions \\
words choice & openness, \\
word variations & reasoning, \\
pressure system & mastery of the topic \\
sentence structure & courage and passion, \\
sentence variations & fluency \\
\hline
\end{tabular}

Thus, students' ability to speak is essentially their ability to express their thoughts, opinions, ideas, and feelings verbally to others, as evidenced by their ability to convey ideas, namely (1) according to their content, (2) with appropriate sentence structures, and (3) with appropriate expressions, (4) word choice or diction, (5) clear voice, (6) proper pronunciation.

\section{Implementing the pragmatic approach in speaking learning skills}

It appears that teachers will find it relatively easy to apply pragmatics in speaking skills because students generally enjoy talking. This means that, in general, if the learning process in the classroom is active, students will be eager to participate in the learning that will take place. The use of pragmatics in speaking skills, such as learning at the Vocational High School (SMK) level in the 12th grade. Speaking with competency standards, namely "expressing thoughts, feelings, and information through introducing, discussing, and telling stories," is an aspect. The fundamental competency is the ability to "introduce oneself and others in official forums with appropriate intonation".

In the learner's strategy. Students are expected to be able to introduce themselves as well as others in an official forum. Before students practice these competencies, the teacher provides material direction. The teacher delivered material in the direction that we must understand the situation in the forum when introducing ourselves and others. This material clearly shows that elements other than language are beginning to be noticed, implying that students are being introduced to pragmatic abilities. Furthermore, the teacher explains what should be considered when speaking (introducing himself) in the official forum, such as where anyone is attending (the students are dealing with), who 
the person is introduced to, what status or position in the forum becomes, what kind of situation is faced, what purpose, and various other things that require attention (referring to pragmatic studies).

Furthermore, the teacher tries to create a situation or learning condition in which students can demonstrate their competence in a situation that has been created. By assigning certain roles to certain people, students are put in situations where they must learn how to deal with certain situations. It will be seen how communication occurs, whether students are able to communicate appropriately in a situation that was created, through the application of learned skills. This achievement can be seen in how the attitude is displayed, how the words are chosen, whether or not the purpose of communication is met, and so on. It is expected that students will gain some knowledge as a result of such a learning process. Furthermore, students are aware of a variety of factors that must be considered during the practical communication process. Finally, students will be provided with opportunities to communicate in society, at least those related to the material being taught.

\section{Speech acts theory and its relevance to Indonesian language teaching}

Speech acts theory is an important component of pragmatic studies. Austin, a British philosopher, divides Speech Acts theory into locutionary, ilocutionary, and perlocutionary categories (Leech, 1983; Simpson, 2006; Stone, 1990). Locutionary act associates a topic with an explanation, similar to the relationship between the subject and the title or the relationship between the topic and the explanation. The act of pronouncing a statement, question, offer, or order. This is based on sentence forms. Perlocutionary act that creates the result or effect of the sentence on the listener based on the situation and conditions of the sentence's pronunciation.

In Teaching and Learning Activities in the Indonesian language, the Listening-Speaking Method is usually used so that students are skilled in composing correct sentences according to Indonesian grammar. In these activities, it is often forgotten that there are actual actions in someone's speech. Besides that, it should be remembered that the real function of language or foremost is a tool to convey meaning or message, or a means of communication. In fact, the true meaning of a Speech Act is the definition of perlocutionary. As a result, variations in speech must be observed in Indonesian Teaching and Learning Activities, particularly in the subject of Language Skills (Pragmatics). (For example, to express an emotional attitude that expresses something interesting, a variety of narrating techniques, among others, can be used.): What a nice dress you have; Ah ... this is just a dress; These were apparently movie star clothes. What needs to be paid greater attention is that behind those expressions there is a real meaning, namely that it means "how nice your clothes are," or that it reveals that your clothes are not good, jealous because your friends have good clothing or just loudly appreciate the fact that people do not have enough clothes, and so on. On the basis of this description, the students' ability to compose grammatical phrases is clearly more than that in their teaching of language skills so that they may communicate. Moreover, they are expected to understand or interpret a speech by someone perlocutionarily, rather than understanding the words of one in an illocutionary way. It is important for Indonesian language teaching and learning to comply with the theories about speech acts.

There are at least three aspects of communication in language. The three components are accuracy, variety based on the communication situation (appropriateness), and fluent expression. These three factors are critical in pragmatic studies and in actual speech. The first aspect is the correct structural aspect, which demonstrates language accuracy. Grammatical sentences typically reflect good speech. At this level, someone who has mastered the language is expected to be able to express himself in appropriate expressions or sentences. The second aspect is the variety aspect in relation to the communication situation, which is actually part of sociolinguistic studies. This is a critical aspect in developing communicative or actual language skills. In this case, a language speaker must pay attention to the context and situation of speech, or the determining factors in language. These determinants include when a person speaks, with whom he speaks, through what channels he speaks, for what purpose he speaks, and so on. As a result, this second aspect is closely related to Pragmatic teaching, and it is even directly related to Pragmatic skills. Pragmatics is simply the use of language to communicate something in relation to context and usage. The third factor is fluency of expression. This aspect becomes the speaking people's last hope. People who (learn) to speak, as is well known, strive to master the language and become fluent in its use.

In such definition, pragmatics plays a critical role in a person's or a language community's linguistic activities. Thus, one who participates in language activities will be able to better understand, fully comprehend, and interpret his speech partner's actual speech (Deda, 2013; Taguchi, 2015; Kecskes, 2000). As a result, the ongoing communication process will be able to run smoothly and miscommunication for true intentions will be avoided. Speaking a proper and correct Indonesian language should begin in Senior High School and continue through university. Teachers must pay attention to the level of difficulty when teaching Pragmatics; it must be appropriate for

Pratiwi, V. U., \& Rohmadi, M. (2021). Pragmatic approach to Indonesian speaking skills for student vocational high schools. International Journal of Linguistics, Literature and Culture, 7(4), 263-273. https://doi.org/10.21744/ijllc.v7n4.1795 
the level of education in which learners participate. This is due to the fact that pragmatic studies incorporate both theoretical and applied practical elements (skills). Indonesian language teachers, at the very least, do not emphasize the theoretical Pragmatic teaching model solely for Vocational High School students. Teachers must be creative in presenting pragmatic-based language practices to students in order for them to be proficient in communicating the Indonesian language.

In general, pragmatic skills are abilities to use language communicatively. This means that the language used is a natural language, not an artificial language. As a result, communicative language materials should be presented in language teaching, i.e. teaching using natural or commonly used language expressions to communicate between users. Pragmatic skills, in general, are abilities to communicate with others through the use of language. This indicates that the language being used is a natural language, as opposed to a computer-generated language. As a result, communicative language materials should be presented in language classes, i.e., teaching users how to communicate using natural, lively language. This can be accomplished, for example, by instructing students to use real language in response to the speech's context.

- Oh, no mum, not ready!

- Ouch, more exams. ...!

- Woooo, not now mum!

- Yes. .., mum!

In terms of the function of communicative language, the various spoken expressions are pragmatically acceptable. The teacher can then choose an example of a student's speech that he believes is inappropriate, keeping in mind that the students are speaking to their teacher. However, both have to pay attention to each other facial expressions and the tone of their voices as they speak. Another utterance, which is expressed with a sullen expression and a deep voice, then the utterance is perlocutionary to mean the opposite, namely that one is not pleased to be given a test In the opposite case, if the utterance is accompanied by a cheerful expression and a light voice, the utterance indicates agreement.which is expressed with a sullen expression and a deep voice, then the utterance is perlocutionary to mean the opposite, namely that one is not pleased to be given a test In the opposite case, if the speech is accompanied by a cheerful expression and a light voice, the utterance indicates agreement. Based on the context of the indicated speech situation, the teacher can explain that the expression is not good or appropriate, keeping in mind that the person speaking should be aware of his or her role as a student towards their teacher, where the teacher should be worthy of respect. The teacher then discussed the students' expressions with them one by one.

This method is more appropriate and communicative than asking students to express their agreement or disagreement about action without accompanying natural and actual language activities. The teacher then asks students to express their agreement and disagreement in written form. The methods described above can also be used to present other Pragmatic aspects such as expressions of satisfaction and dissatisfaction, convincing expressions, expressions of something making sense or not, and so on.

\section{Conclusion}

Language learning teaches language students the importance of a pragmatic approach to speaking skills. The achievement of appropriate language competence in language learning must not only be supported through the structural study of language but also through learning about external aspects that frequently influence the communication process. Students will become more familiar with the practical conditions of speaking both orally and in writing if they are exposed to a pragmatic approach as much as possible. Furthermore, because Indonesia has such a diverse culture, including language, a pragmatic approach to language learning will address any potential challenges. Due to the large number of policies left to each level of education in the 2013 curriculum, the learning (particularly language) that emerged would be better able to meet the needs of students. Thus, learning speaking skills with a pragmatic approach is very effective in enhancing active learning, especially in improving students' speaking skills in and out of the classroom.

\section{Conflict of interest statement}

The author(s) declared that they have no competing interest. 
Statement of authorship

The authors have a responsibility for the conception and design of the study. The authors have approved the final article.

Acknowledgments

We are grateful to two anonymous reviewers for their valuable comments on the earlier version of this paper.

Pratiwi, V. U., \& Rohmadi, M. (2021). Pragmatic approach to Indonesian speaking skills for student vocational high schools. International Journal of Linguistics, Literature and Culture, 7(4), 263-273. https://doi.org/10.21744/ijllc.v7n4.1795 


\section{References}

Angelina, P. (2019). Improving Indonesian EFL students' speaking skill through PechaKucha. LLT Journal: A Journal on Language and Language Teaching, 22(1), 86-97.

Cavendish, J. C. (1995). Integrating feature-based surface design with freeform deformation. Computer-Aided Design, 27(9), 703-711. https://doi.org/10.1016/0010-4485(95)00011-F

Chaniago, S. M., \& Mukti, U. S. Maidar Arsyad. 1997. Pragmatik. Jakarta: Universitas Terbuka.

Crystal, D. (2011). A dictionary of linguistics and phonetics (Vol. 30). John Wiley \& Sons.

Davies, A. (2007). Introduction to applied linguistics: From practice to theory: from practice to theory. Edinburgh University Press.

de Pablos-Ortega, C. (2011). The pragmatics of thanking reflected in the textbooks for teaching Spanish as a foreign language. Journal of Pragmatics, 43(9), 2411-2433. https://doi.org/10.1016/j.pragma.2011.02.016

Deda, N. (2013). The role of Pragmatics in English language teaching. Pragmatic competence. Academic Journal of Interdisciplinary Studies, 2(4), 63-63.

del Saz Rubio, M. M. (2011). A pragmatic approach to the macro-structure and metadiscoursal features of research article introductions in the field of Agricultural Sciences. English for Specific Purposes, 30(4), 258-271. https://doi.org/10.1016/j.esp.2011.03.002

Eslami-Rasekh, Z., Eslami-Rasekh, A., \& Fatahi, A. (2004). The Effect of Explicit Metapragmatic Instruction on the Speech Act Awareness of Advanced EFL Students. TESL-EJ, 8(2), n2.

Evans, S., \& Green, C. (2007). Why EAP is necessary: A survey of Hong Kong tertiary students. Journal of English for Academic Purposes, 6(1), 3-17. https://doi.org/10.1016/j.jeap.2006.11.005

Holland, A. L. (1991). Pragmatic aspects of intervention in aphasia. Journal of Neurolinguistics, 6(2), $197-211$. https://doi.org/10.1016/0911-6044(91)90007-6

Huberman, M., \& Miles, M. B. (2002). The qualitative researcher's companion. Sage.

Jorda, M. P. S. (2004). An analysis on EAP learners' pragmatic production: a focus on request forms. Ibérica, Revista de la Asociación Europea de Lenguas para Fines Específicos, (8), 23-39.

Jordà, S. (2004, November). Digital instruments and players: Part ii-diversity, freedom and control. In ICMC.

Kasper, G., \& Rose, K. R. (1999). Pragmatics and SLA. Annual review of applied linguistics, 19, 81-104.

Kecskes, I. (2000). A cognitive-pragmatic approach to situation-bound utterances. Journal of pragmatics, 32(5), 605625. https://doi.org/10.1016/S0378-2166(99)00063-6

Kusmiarti, R., \& Yuniati, I. (2020). Improving Student Communication Skills in Learning Indonesian Language Through Collaborative Learning.

Leech, G. N. (1983). 1983, Principles of Pragmatics. London; New-York.

Levinson, S. C. (1997). From outer to inner space: linguistic categories and non-linguistic thinking (pp. 13-45). Cambridge University Press.

Mulyani, M. (2019, June). Kajian pragmatik terhadap materi pembelajaran pada silabus bahasa inggris wajib kelas $\mathrm{x}$ sma kurikulum 2013. In Seminar Nasional Pendidikan 2015 (pp. 456-464).

Nababan, P. W. J. (1987). Ilmu pragmatik (teori dan penerapannya). Jakarta: Depdiknas.

Nurhadi, T. B. P. (1995). Landasan Penyusunan Buku Pelajaran Bahasa. Semarang: IKIP Semarang Press, tt.

Paul, R. (2008). Interventions to improve communication in autism. Child and adolescent psychiatric clinics of North America, 17(4), 835-856. https://doi.org/10.1016/j.chc.2008.06.011

Rohmadi, M. (2014). Kajian pragmatik percakapan guru dan siswa dalam pembelajaran bahasa Indonesia. Paedagogia, 17(1), 53-61.

Simpson, J. (2006). Differing expectations in the assessment of the speaking skills of ESOL learners. Linguistics and Education, 17(1), 40-55. https://doi.org/10.1016/j.linged.2006.08.007

Stone, M. H. (1990). Treatment of borderline patients: a pragmatic approach. Psychiatric Clinics, 13(2), $265-285$. https://doi.org/10.1016/S0193-953X(18)30366-6

Sutopo, H. B. (1996). Metodologi penelitian kualitatif (Metodologi penelitian untuk ilmu-ilmu sosial dan budaya). Surakarta: Universitas Sebelas Maret Surakarta.

Taguchi, N. (2015). "Contextually" speaking: A survey of pragmatic learning abroad, in class, and online. System, 48, 3-20. https://doi.org/10.1016/j.system.2014.09.001

Taguchi, N. (2018). Description and explanation of pragmatic development: Quantitative, qualitative, and mixed methods research. System, 75, 23-32. https://doi.org/10.1016/j.system.2018.03.010

Tarigan, H. G. (2008). Reading as a language skill. Bandung: Angkasa.

Tarvin, L. D. (2014). Communicative competence: its definition, connection to teaching, and relationship with 
interactional competence. Education Specialists Thesis. University of Missouri. Retrieved from: https://www. academia. edu/19300994/Communicative_Competence_Its_Definition_Conn ection_to_Teaching_and_Relationship_with_Interactional_Competence.

Torky, S. A. E. (2006). The Effectiveness of a Task-Based Instruction Program in Developing the English Language Speaking Skills of Secondary Stage Students. Online Submission.

Van Wynsberghe, A., \& Robbins, S. (2014). Ethicist as designer: a pragmatic approach to ethics in the lab. Science and engineering ethics, 20(4), 947-961. https://doi.org/10.1007/s11948-013-9498-4

Widiasri, D. A., Budiarsa, M., Sudipa, I. N., \& Satyawati, M. S. (2019). Speech act in Indonesian language teaching: an ethnography communication study. International Journal of Linguistics, Literature and Culture, 5 (5), $55-62$.

Yohanes, B. (2006). Pragmatic Approach. http://digilib.upi.edu/pasca/available/etd-1127106-110028/

Yule, G. (2000). Pragmatics (5th Impression). Oxford Oxford University Press.

Pratiwi, V. U., \& Rohmadi, M. (2021). Pragmatic approach to Indonesian speaking skills for student vocational high schools. International Journal of Linguistics, Literature and Culture, 7(4), 263-273. https://doi.org/10.21744/ijllc.v7n4.1795 